\title{
Congenital mesonephric defects in male infants with mucoviscidosis
}

\author{
J. R. OLSON AND D. K. WEAVER \\ From the Department of Pathology, The University of Michigan Medical Center, Ann Arbor, \\ Michigan, USA
}

SYNOPSIS Reports that men with mucoviscidosis were sterile and that portions of their genital tracts were atretic prompted us to investigate the genital tracts of 15 male infants with mucoviscidosis who died within the first year of life and came to necropsy. The genital tracts of all of these infants were abnormal, the abnormalities being confined to mesonephric derivatives. Hypoplastic or absent ducti efferentia, ducti epididymides, or ducti deferentia were found in all 28 specimens of epididymides, and the ducti deferentia were missing from 25 of 27 examples of spermatic cord. The seminal vesicles and the ejaculatory ducts were less frequently hypoplastic or absent. Because these abnormalities of mesonephric derivatives were present so early in life and inflammatory and obstructive changes were absent we believe that they resulted from a failure of development.

An outcome of the lengthening of life of patients with mucoviscidosis is the realization that those who reach adulthood and are male are infertile. Denning, Sommers, and Quigley (1968) reported azoospermia in nine patients with mucoviscidosis. Kaplan, Shwachman, Perlmutter, Rule, Khaw, and Holsclaw (1968) confirmed that their 25 adult male patients with mucoviscidosis had azoospermia. Furthermore, 10 males from 5 to 20 years of age were found at necropsy to have absent ducti deferentia and five of six had incompletely developed epididymides. Seven patients from 3 to 24 years of age underwent surgical exploration of the spermatic cord and in all the ducti deferentia were absent.

Left unresolved was the age at which these abnormalities first appeared, since the youngest patient reported by Kaplan et al (1968) was 3 years old. Our study was undertaken to find out if such abnormalities occur in the genital tract of infant males with mucoviscidosis and, if they do, to determine if the lesions are congenital or acquired.

\section{METHODS AND MATERIALS}

Material from the genital tract of 15 male infants was obtained from necropsies performed in The University of Michigan Medical Centre between 1946 and 1968. All of the infants had histological (Bodian, 1952) and clinical manifestations of mucoviscidosis. In 14 cases fixed but unblocked tissue was available. This stock was

Received for publication 20 March 1969. serially blocked and, in selected instances, serially sectioned. In cases 2, 4, and 10 enough material was available to enable us to dissect bilaterally the testis, epididymis, spermatic cord, seminal vesicle, and prostate gland. In case 6 , these tissues were available for complete dissection from one side only. Significant portions of the testes and genital tracts were available from both sides of nine of the 11 remaining subjects; in the other two the material was available from one side only. Control tissues of mesonephric derivatives were obtained from six male infants who had died in accidents, suddenly and unexpectedly in so-called 'cot deaths', or from neoplasms.

The epididymides, spermatic cords, seminal vesicles, and ejaculatory ducts were examined in all subjects and designated normal, absent, or hypoplastic. The last term referred to those mesonephric derivatives which contained less than one-half the number of units present in the controls.

\section{RESULTS}

The age of the patients and the results are summarized in Table I.

THE EPIDIDYMIS Grossly the epididymis either appeared normal or hypoplastic. Three epithelial parts of 28 epididymides were examined microscopically: the ductuli efferentes, the ductus epididymis, and the ductus deferens (Figs. 1a and 1b). The ductuli efferentes were absent in 12 specimens; however, they were absent bilaterally in 
TABLE I

SUMMARY OF ABNORMALITIES ${ }^{1}$

\begin{tabular}{|c|c|c|c|c|c|c|c|c|}
\hline \multirow[b]{2}{*}{ Case } & \multirow[b]{2}{*}{ Age } & \multicolumn{3}{|l|}{ Epididymis } & \multicolumn{2}{|l|}{ Spermatic Cord } & \multirow{2}{*}{ Seminal Vesicle } & \multirow{2}{*}{$\begin{array}{c}\text { Ejaculatory } \\
\text { Duct }\end{array}$} \\
\hline & & $\begin{array}{l}\text { Ductuli } \\
\text { Efferentes }\end{array}$ & $\begin{array}{l}\text { Ductus } \\
\text { Epididymis }\end{array}$ & $\begin{array}{l}\text { Ductus } \\
\text { Deferens }\end{array}$ & $\begin{array}{l}\text { Ductus } \\
\text { Deferens }\end{array}$ & Paradidymis & & \\
\hline 1 & 9 days & $\begin{array}{l}\text { Hypoplast ic } \\
\text { Hypoplast ic }\end{array}$ & $\begin{array}{l}\text { Hypoplastic } \\
\text { Absent }\end{array}$ & $\begin{array}{l}\text { Absent } \\
\text { Hypoplastic with atresia } \\
\text { of the epithelium }\end{array}$ & $\begin{array}{l}\text { Absent } \\
\text { Absent }\end{array}$ & & & \\
\hline 2 & 9 days & $\begin{array}{l}\text { Absent } \\
\text { Hypoplast ic }\end{array}$ & $\begin{array}{l}\text { Absent } \\
\text { Hypoplastic }\end{array}$ & $\begin{array}{l}\text { Absent } \\
\text { Absent }\end{array}$ & $\begin{array}{l}\text { Normal } \\
\text { Absent }\end{array}$ & & $\begin{array}{l}\text { Normal } \\
\text { Normal }\end{array}$ & $\begin{array}{l}\text { Normal } \\
\text { Normal }\end{array}$ \\
\hline 3 & 15 days & Hypoplast ic & Hypoplastic & Absent & Absent & & & $\begin{array}{l}\text { Normal } \\
\text { Normal }\end{array}$ \\
\hline 4 & 18 days & Absent & Hypoplastic & Absent & Absent & Normal & $\begin{array}{l}\text { Hypoplastic with atresia of } \\
\text { the epithelium }\end{array}$ & Absent \\
\hline 5 & 20 days & $\begin{array}{l}\text { Absent } \\
\text { Hypoplastic } \\
\text { Absent }\end{array}$ & $\begin{array}{l}\text { Hypoplast ic } \\
\text { Hypoplast ic } \\
\text { Absent }\end{array}$ & $\begin{array}{l}\text { Absent } \\
\text { Normal } \\
\text { Absent }\end{array}$ & $\begin{array}{l}\text { Absent } \\
\text { Hypoplastic } \\
\text { Absent }\end{array}$ & $\begin{array}{l}\text { Normal } \\
\text { Normal }\end{array}$ & $\begin{array}{l}\text { Absent } \\
\text { Absent } \\
\text { Hypoplastic with atresia of } \\
\text { the epithelium }\end{array}$ & Absent \\
\hline 6 & 8 wk & $\begin{array}{l}\text { Hypoplastic } \\
\text { Absent }\end{array}$ & $\begin{array}{l}\text { Hypoplastic } \\
\text { Absent }\end{array}$ & $\begin{array}{l}\text { Hypoplast ic } \\
\text { Normal }\end{array}$ & Absent & & Normal & Normal \\
\hline 7 & $10 \mathrm{wk}$ & $\begin{array}{l}\text { Hypoplast ic } \\
\text { Hypoplast ic }\end{array}$ & $\begin{array}{l}\text { Hypoplast ic } \\
\text { Hypoplast ic }\end{array}$ & $\begin{array}{l}\text { Absent } \\
\text { Absent }\end{array}$ & $\begin{array}{l}\text { Absent } \\
\text { Absent }\end{array}$ & & $\begin{array}{l}\text { Absent } \\
\text { Hypoplastic with atresia of } \\
\text { the epithelium }\end{array}$ & \\
\hline 8 & $10 \mathrm{wk}$ & $\begin{array}{l}\text { Absent } \\
\text { Hypoplastic }\end{array}$ & $\begin{array}{l}\text { Absent } \\
\text { Absent }\end{array}$ & $\begin{array}{l}\text { Absent } \\
\text { Absent }\end{array}$ & $\begin{array}{l}\text { Absent } \\
\text { Absent }\end{array}$ & & & \\
\hline 9 & $3 \mathrm{mth}$ & $\begin{array}{l}\text { Absent } \\
\text { Hypoplastic }\end{array}$ & $\begin{array}{l}\text { Absent } \\
\text { Hypoplastic }\end{array}$ & $\begin{array}{l}\text { Absent } \\
\text { Absent }\end{array}$ & $\begin{array}{l}\text { Absent } \\
\text { Absent }\end{array}$ & & Normal & \\
\hline 10 & $3 \mathrm{mth}$ & $\begin{array}{l}\text { Hypoplast ic } \\
\text { Hypoplast ic }\end{array}$ & $\begin{array}{l}\text { Hypoplast ic } \\
\text { Hypoplast ic }\end{array}$ & $\begin{array}{l}\text { Absent } \\
\text { Absent }\end{array}$ & $\begin{array}{l}\text { Absent } \\
\text { Absent }\end{array}$ & $\begin{array}{l}\text { Normal } \\
\text { Normal }\end{array}$ & $\begin{array}{l}\text { Absent } \\
\text { Normal }\end{array}$ & $\begin{array}{l}\text { Normal } \\
\text { Normal }\end{array}$ \\
\hline 11 & $3.5 \mathrm{mth}$ & Absent & Hypoplastic & Absent & Absent & & $\begin{array}{l}\text { Absent } \\
\text { Absent }\end{array}$ & $\begin{array}{l}\text { Absent } \\
\text { Absent }\end{array}$ \\
\hline 13 & $\begin{array}{l}6.5 \mathrm{mth} \\
8 \mathrm{mth}\end{array}$ & $\begin{array}{l}\text { Absent } \\
\text { Absent } \\
\text { Absent } \\
\text { Absent }\end{array}$ & $\begin{array}{l}\text { Hypoplastic } \\
\text { Hypoplastic } \\
\text { Hypoplastic } \\
\text { Hypoplast ic }\end{array}$ & $\begin{array}{l}\text { Absent } \\
\text { Absent } \\
\text { Absent } \\
\text { Absent }\end{array}$ & $\begin{array}{l}\text { Absent } \\
\text { Absent } \\
\text { Absent } \\
\text { Absent }\end{array}$ & $\begin{array}{l}\text { Normal } \\
\text { Normal } \\
\text { Normal } \\
\text { Normal }\end{array}$ & Normal & \\
\hline 14 & $11 \mathrm{mth}$ & $\begin{array}{l}\text { Hypoplast ic } \\
\text { Hypoplast ic } \\
\text { Hypoplast ic } \\
\text { Hypoplast ic }\end{array}$ & $\begin{array}{l}\text { Absent } \\
\text { Hypoplast ic } \\
\text { Hypoplastic } \\
\text { Hypoplast ic }\end{array}$ & $\begin{array}{l}\text { Normal } \\
\text { Normal } \\
\text { Absent } \\
\text { Absent }\end{array}$ & $\begin{array}{l}\text { Absent } \\
\text { Absent } \\
\text { Absent } \\
\text { Absent }\end{array}$ & $\begin{array}{l}\text { Normal } \\
\text { Normal } \\
\text { Normal }\end{array}$ & $\begin{array}{c}\text { Normal } \\
\text { Normal } \\
\text { Normal }\end{array}$ & \\
\hline Total & & 28 & 28 & 28 & 27 & 12 & 18 & 11 \\
\hline
\end{tabular}

${ }^{1}$ In cases $6,9,12$, and 15 , the seminal vesicles and ejaculatory ducts did not necessarily come from the same side as the epididymides and spermatic cords.

only three subjects (Table I). In 16 specimens, the ductuli efferentes were hypoplastic; in none of the material were the ductuli efferentes normal. The ductus epididymis was absent in eight specimens. The ductus epididymis was absent on both sides in only one subject. The remaining 20 epididymides all had hypoplasia of the ductus epididymis. Within the 28 epididymides, the ductus deferens was absent in 22, hypoplastic in one, hypoplastic with atresia of the epithelium in one, and normal in four. The ductus deferens was bilaterally absent in nine subjects.

THE SPERMATIC CORD The ductus deferens was sought for in 27 specimens. It was absent at all levels of the spermatic cord in six of the seven examples where the entire cord was available even though the spermatic cord was normal externally in all cases. In 19 specimens, the ductus deferens was absent at the levels represented in the stock material. One ductus was hypoplastic with a stenotic lumen (Fig. 2a) and one was normal. In three cases nodular proliferations of smooth muscle representing the ductus deferens with absent epithelium were found only at the proximal or distal ends of the spermatic cord (Fig. 2b). The ductus deferens was absent bilaterally in 10 subjects. Paradidymis was found in 12 of 27 specimens. This mesonephric remnant (Fig. 3) should not be confused with the ductus deferens. We did not find any abnormalities of the 


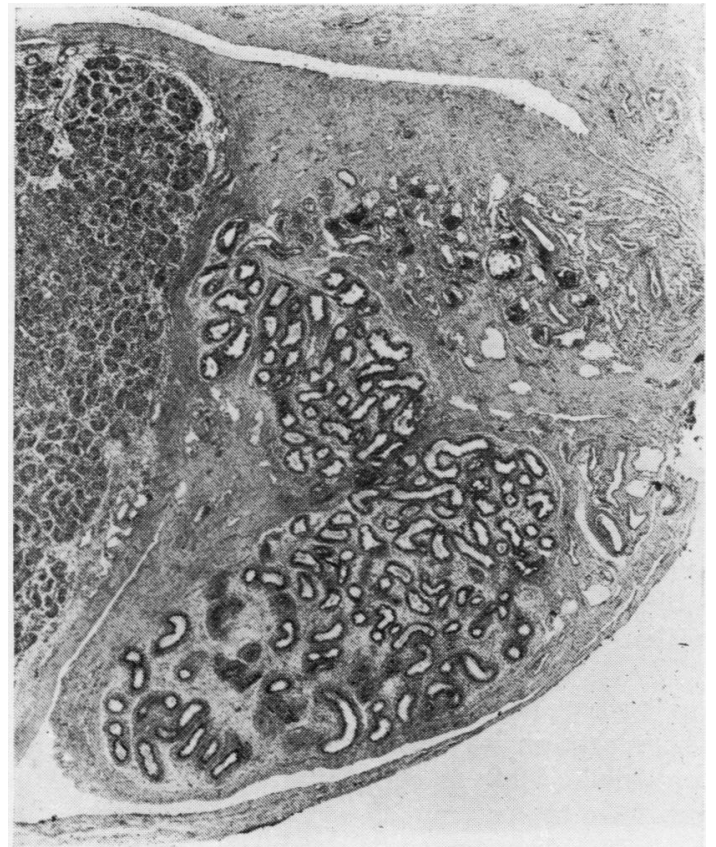

FIG. 1a.

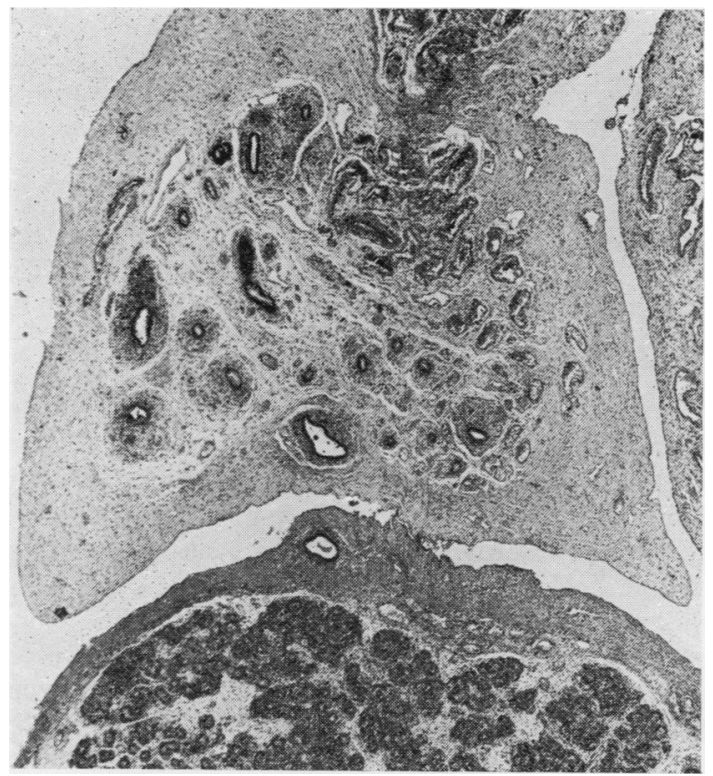

FIG. 1 b.

FIG. 1a. Normal epididymis of 3-month-old; death due to metastatic neuroblastoma. Haematoxylin $\times 24$.

FIG. 1b. Mucoviscidosis, case 2. Hypoplasia of epididymis. Haematoxylin and eosin $\times 30$.

FIGS. 2a and 2b. (a) Mucoviscidosis, case 5. Ductus deferens (within spermatic cord); stenosis of the lumen. Haematoxylin and eosin $\times 125$. (b) Mucoviscidosis, case 7. Ductus deferens (adjacent to seminal vesicle); atresia of epithelium. Ductus deferens was absent within the spermatic cord. Haematoxylin and eosin $\times 130$.

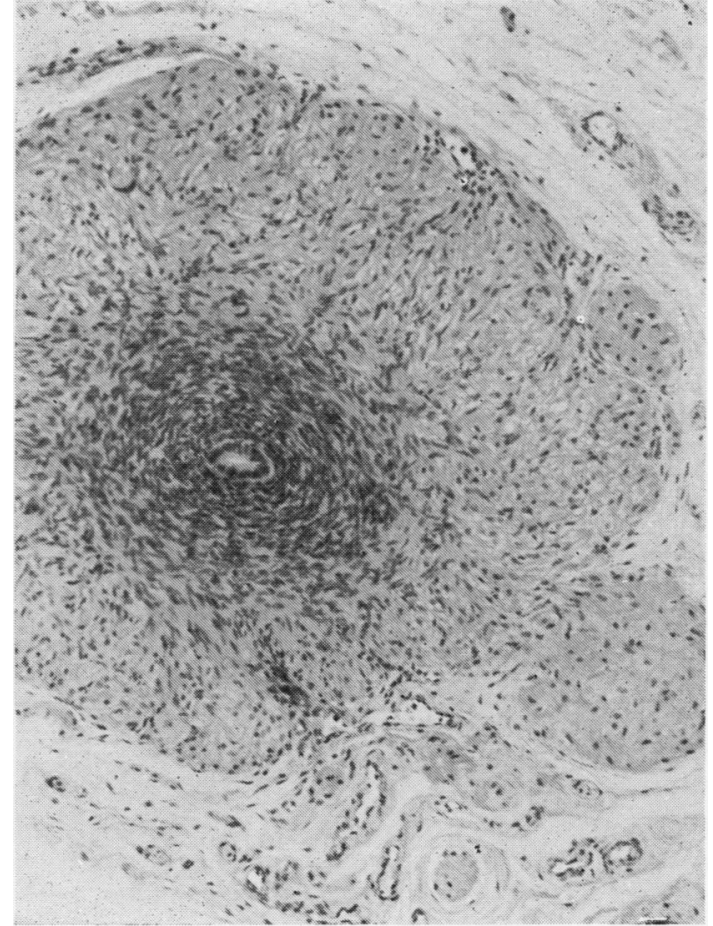

FIG. 2a.



FIG. $2 b$. 


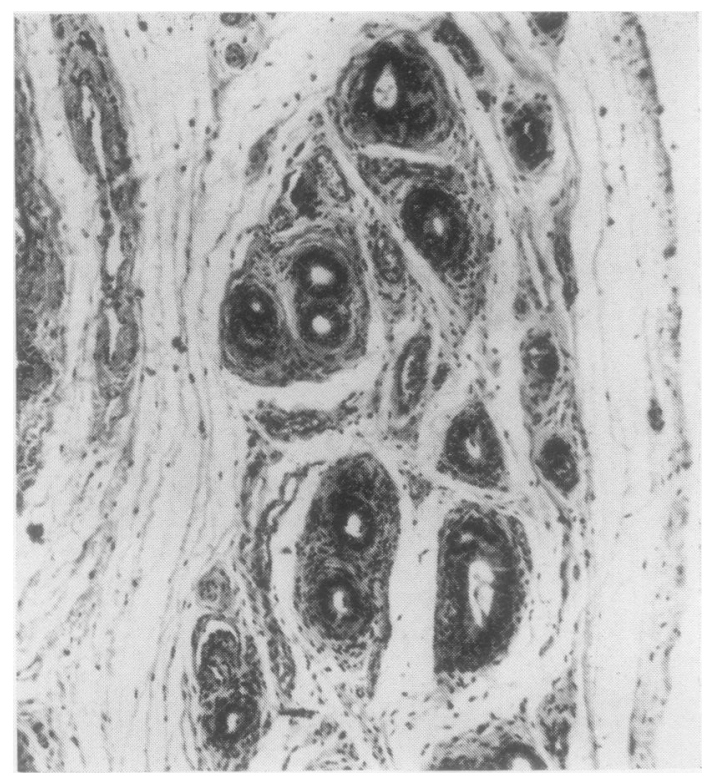

FIG. 3. Mucoviscidosis, case 10. Paradidymis within spermatic cord. This structure should not be confused with the ductus deferens. Haematoxylin and eosin $\times 140$.

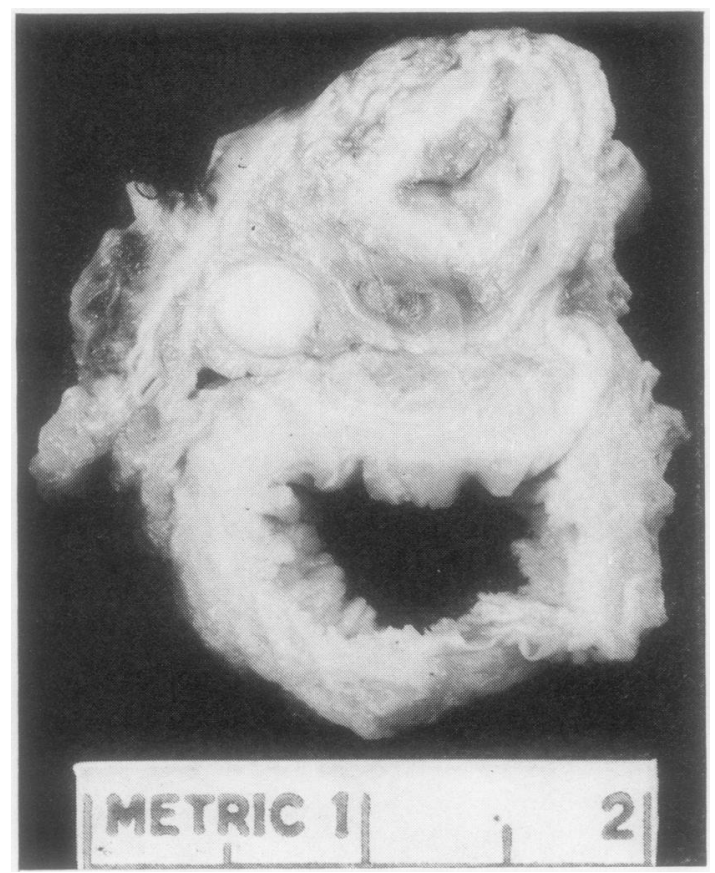

FIG. 4. Mucoviscidosis, case 4. Absence of the left seminal vesicle. Large intestine is at the top and urinary bladder at the bottom. spermatic artery or veins, interstitial connective tissues, or the cremaster muscle.

THE SEMINAL VESICLE Eighteen vesicles could be evaluated in 11 subjects. In four of the subjects the seminal vesicle was absent on one side, and in three of these four (Fig. 4) the opposite seminal vesicle was hypoplastic and devoid of epithelium (Figs. 5a and b). The seminal vesicle was absent bilaterally in one subject. Nine seminal vesicles were normal in seven subjects; in two of these seven the seminal vesicles were normal on both sides.

THE EJACULATORY DUCT In six subjects, 11 ejaculatory ducts were evaluated. The ejaculatory ducts were absent bilaterally in two of the subjects: four subjects had normal ejaculatory ducts, three bilaterally.

THE TESTIS All the testes except one were normal. The exception was the left testis in case 1 which contained a large recent haemorrhagic infarct. This may have been secondary to abdominal surgery for meconium ileus on the day of birth. Germinal cells were recognized within the seminiferous tubules of all the testes.

THE PROSTATE All the prostate glands were normal except for those subjects with absent ejaculatory ducts.

CONTROLS No abnormalities were found in the testes, epididymides, spermatic cords, seminal vesicles, ejaculatory ducts, and prostate glands of the six control subjects.

\section{DISCUSSION}

We found that abnormalities of the genital tract in infants who had died from mucoviscidosis were confined to mesonephric derivatives. Absence of the ductus deferens, either in the spermatic cord or in the epididymis, and hypoplasia or aplasia of portions of the epididymis were the commonest abnormalities, occurring on at least one side in all 15 subjects (Table I). Less frequently affected was the distal portion of the mesonephric system inasmuch as normal seminal vesicles and ejaculatory ducts were present in 11 of 18 specimens. Although only mesonephric derivatives were found to be abnormal, the abnormalities varied in extent and severity between subjects and in the same subject.

Table I illustrates the variety of abnormalities of the derivatives of the mesonephric system. In case 14, for example, the ductus deferens within the epididymis was normal, but within the spermatic 


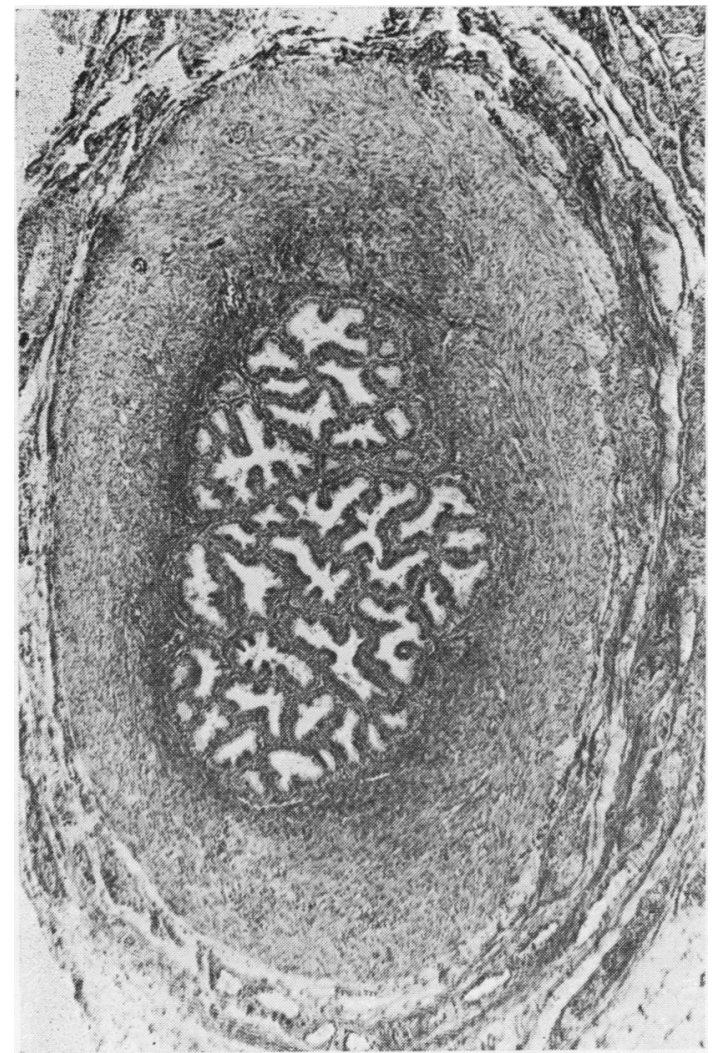

FIG. 5a.

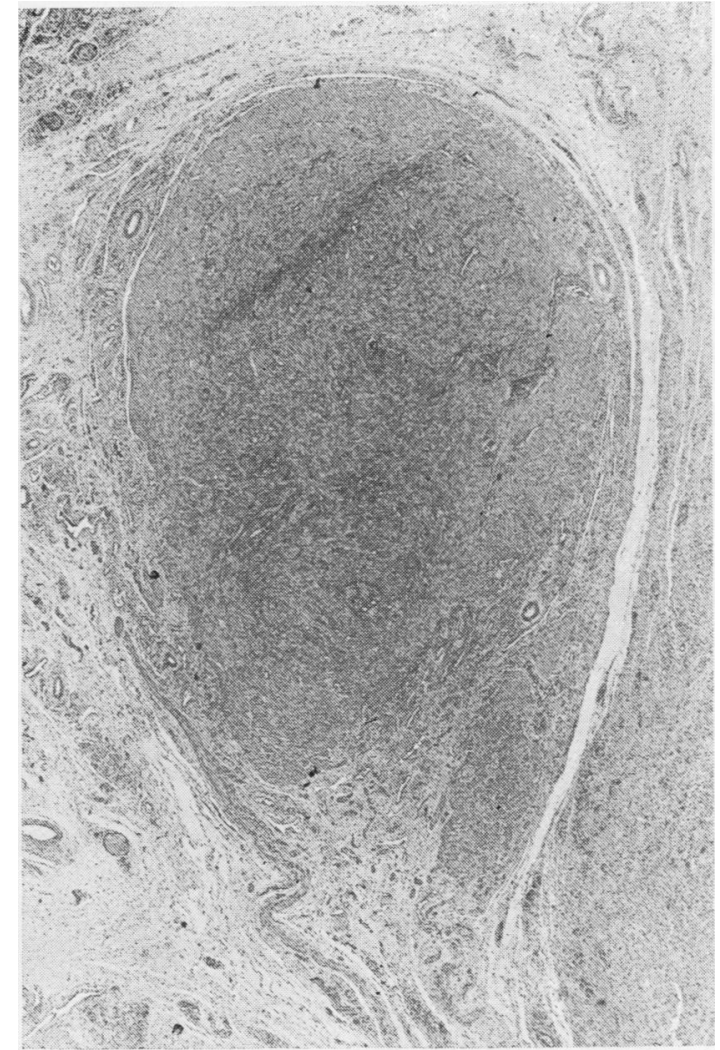

FIG. 5 b.

FIG. 5a. Normal seminal vesicle of 5-month-old; 'cot death' due to acute catarrhal tracheobronchitis. Haematoxylin and eosin $\times 50$.

FIG. 5b. Mucoviscidosis, case 4. Right seminal vesicle with atresia of epithelium. Haematoxylin and eosin $\times 30$.

cord it was absent. On the other hand, case 2 presented with the opposite findings, a ductus deferens in the spermatic cord, but not in the epididymis. Also, the severity of the malformations varied. In some subjects a structure was normal whereas in others it was absent, and between these two extremes a variety of abnormalities existed. For example, in some subjects, the ductus deferens and seminal vesicles were normal, whereas in others they were represented merely by a nodular proliferation of smooth muscle devoid of epithelium. This variation in extent and severity of abnormalities was also noted by Kaplan et al (1968).

The cause of these abnormalities is unknown. Three possibilities are considered: the lesions may be acquired after birth, the result of obstruction and inflammation; acquired in utero by a similar mechanism; or may result from faulty morphogenesis of the mesonephric system.

The first possibility, that the lesions are acquired after birth, is not supported by our findings. The most severe lesions, complete absence of seminal vesicles and the ductus deferens and portions of the epididymis, were present in neonates only 9 days old; it is difficult to conceive of an obstructive and inflammatory process so rapid that absence of even a part of these structures could be produced in so short a time. Furthermore, the lesions in the older subjects were no more severe than in the younger. The morphological changes associated with mucoviscidosis, inspissated secretions and dilated ducts, necrosis and atrophy of ductal epithelium, and fibrosis of surrounding interstitial connective tissue, were not present in the genital tracts of our subjects. Di Sant' Agnese (1968) suggested that abnormalities of the genital tract in mucoviscidosis, like atresia of the intestine and gallbladder, resulted from common mechanisms and were acquired in utero. The epididymal epithelium does secrete periodic acid Schiff-positive material from the 25 th week of 
gestation until after birth (Zondek and Zondek, 1965). Thus the production of viscid inspissated secretions with resulting obstruction, epithelial necrosis, and obliterative fibrosis is possible. Against such a sequence of events is the absence of such changes in the material we examined. In fact, one of the most prominent findings in our material is the absence of portions of the mesonephric derivatives so that not even a fibrous cord, an expected legacy of atresia, remains. For these reasons, we do not believe that the absence of portions of the genital ducts in mucoviscidosis is an acquired lesion.

The most logical explanation for the anatomical abnormalities is that they resulted from faulty morphogenesis of the mesonephric system. Congenital abnormalities of the ductus deferens and epididymis, unassociated with mucoviscidosis, have been reported. Michelson (1949) reviewed 74 cases of maldeveloped mesonephric systems; 18 patients had unilateral and two patients bilateral absence of the ductus deferens. Amelar and Hotchkiss (1963) recently described 10 more examples of infertile men with bilaterally absent ducti deferentia and epididymides. These reports attest to the presence of abnormalities of mesonephric derivatives which are, presumably, of developmental origin. We believe that Kaplan's suggestion, that the abnormalities of the mesonephric system in adults are developmental, also applies to the cases we have described.

The genesis of the genital tract lesions remains obscure. Two possible mechanisms are suggested.
One, that the genital lesions result from the same basic inborn error of metabolism responsible for lesions elsewhere. Johansen, Anderson, and Hadorn (1968) postulate that the basic defect in mucoviscidosis is an abnormality of extracellular mucopolysaccharides which might impede free movement of water between the lumen and extracellular space in glands and ducts. Perhaps such an abnormal ground substance may impede the development of the mesonephric system. The other possibility is that the defect in the mesonephric system is unrelated to the gene causing mucoviscidosis. If the defects are genetically induced then the gene responsible for the mesonephric abnormalities must be closely linked to the gene responsible for the inborn error in mucoviscidosis.

In all probability the dénouement of the cause of the mesonephric abnormalities will have to await the discovery of the basic defect causing mucoviscidosis.

\section{REFERENCES}

Amelar, R. D., and Hotchkiss, R. S. (1963). Fertil. and Steril., 14, 44. Bodian, M. (1952). Fibrocystic Disease of the Pancreas; a Congenital Disorder of Mucous Production-Mucosis. Heinemann, London.

Denning, C. R., Sommers, S. C., and Quigley, H. J., Jr. (1968). Pediatrics, 41, 7.

Di Sant'Agnese, P. A. (1968). New Engl. J. Med., 279, 103.

Johansen, P. G., Anderson, C. M., and Hadorn, B. (1968). Lancet, $1,455$.

Kaplan, E., Shwachman, H., Perlmutter, A. D., Rule, A., Khaw, K.T, and Holsclaw, D. S. (1968). New Engl. J. Med., 279, 65.

Michelson, L. (1949). J. Urol. (Baltimore), 61, 384.

Zondek, L. H., and Zondek, T. (1965). Acta paediat. (Scand.), $54,295$. 